\title{
LEGAL STATUS OF INDIVIDUAL BANKRUPT DEBTORS AFTER TERMINATION OF BANKRUPTCY AND REHABILITATION UNDER INDONESIAN BANKRUPTCY LAW
}

\author{
Sonyendah Retnaningsih* and Isis Ikhwansyah**
}

\begin{abstract}
* Faculty of Law Universitas Indonesia
** Faculty of Law, Padjajaran University
\end{abstract}

\section{Article Info}

Received : 18 August 2016 | Received in revised form : 13 December 2016 | Accepted : 23 March 2017 Corresponding author's e-mail : ade_retno_1993@yahoo.com

\begin{abstract}
The Indonesian bankruptcy law system adheres to the debt collective principle which is general seizure (sita umum) of the debtor's property as guarantee for the payment of debt through the bankruptcy institution. The principle of debt collective stresses that the debtor's debt shall be paid immediately from the property owned by the debtor. Based on such principle, bankruptcy serves as a means of coercion to materialize the creditors' rights through liquidation of the debtor's assets. Bankruptcy law in Indonesia does not recognize the principle of debt forgiveness, among others, the implementation of debt relief granted to the debtor to pay off debts that are truly incapable of being fulfilled. According to the Bankruptcy Law, after the completion of the bankruptcy process, the debtor is no longer in a state of bankruptcy, because the end of bankruptcy has revoked the status of insolvent debtors, hence debtors are considered as being competent to take care of their property. However, the termination of bankruptcy does not necessarily absolve the debtor from the remainder of the debt; creditors are entitled to collect it and debtors are obligated to pay it off. Upon the completion of the bankruptcy process, debtors or their heirs may apply for rehabilitation. However, rehabilitation is only to be granted if all creditors state that they have obtained payment in a satisfactory manner, meaning that recognized creditors will not file claims against the debtor concerned again even though they may not have received payment on all of their outstanding receivables. Request for rehabilitation can only be granted if the debtor has completed the entire scheme of bankruptcy and creditors were satisfied with the payment.
\end{abstract}

Keywords: debt collective, debt forgiveness, termination of bankruptcy, rehabilitation

\begin{abstract}
Abstrak
Sistem Hukum Kepailitan di Indonesia menganut prinsip debt collective yaitu sita umum atas harta debitor sebagai jaminan pelunasan atas utang-utangnya melalui lembaga kepailitan. Prinsip debt collective menekankan bahwa utang debitor harus dibayar dengan harta yang dimiliki oleh debitor sesegera mungkin. Berdasarkan prinsip ini, kepailitan berfungsi sebagai sebagai sarana pemaksa untuk merealisasikan hakhak kreditor melalui proses likuidasi terhadap harta kekayaan debitor. Hukum Kepailitan di Indonesia tidak mengenal prinsip debt forgiveness, yang implementasinya antara lain berupa diberikannya penghapusan utang debitor untuk membayar utang-utangnya yang benar-benar tidak dapat dipenuhinya. Menurut UUK \& PKPU, setelah berakhirnya kepailitan, maka debitor tidak lagi berada dalam keadaan pailit, karena berakhirnya kepailitan telah mencabut status pailit debitor, sehingga debitor dianggap cakap untuk mengurus kembali harta bendanya, akan tetapi pengakhiran kepailitan tidak serta merta membebaskan debitor dari sisa utang. Kreditor berhak untuk menagih dan debitor wajib untuk melunasinya. Setelah pengakhiran kepailitan, debitor atau ahli warisnya dapat mengajukan permohonan rehabilitasi, akan tetapi rehabilitasi akan dikabulkan jika semua kreditornya menyatakan sudah memperoleh pembayaran secara memuaskan, artinya kreditor yang diakui tidak akan mengajukan tagihan lagi terhadap debitor sekalipun mereka mungkin tidak menerima pembayaran atas seluruh tagihannya. Permohonan rehabilitasi hanya dapat diberikan jika debitor telah menyelesaikan seluruh skema kepailitan dan kreditor merasa puas dengan pembayaran yang ada.
\end{abstract}

Kata kunci : debt collective, debt forgiveness, pengakhiran kepailitan, rehabilitasi. 


\section{INTRODUCTION}

The Indonesian Law on Bankruptcy and Suspension of Obligation for Payment of Debts (Undang-Undang Kepailitan dan Penundaan Kewajiban Pembayaran Utang, hereinafter referred to as "Bankruptcy Law") ${ }^{1}$ system adheres to the debt collective principle that is general seizure of debtor's property as guarantee for the payment of their debts through the bankruptcy institution. The principle of debt collective emphasizes that the debt shall be paid immediately from property owned by the debtor in order to avoid the possibility of the debtor's bad faith by hiding and distorting its property as collateral for the repayment of debts to the creditors. ${ }^{2}$ Based on the principle of debt collective, bankruptcy serves as a means of coercion to materialize the rights of creditors through liquidation of the debtor's assets. The principle of debt collective in the modern era is manifested in the form of liquidation of assets. ${ }^{3}$

The principle of debt collective is affirmed in Article 1 (1) of the Bankruptcy Law stating that bankruptcy is a general seizure of the debtor's property to guarantee payment of its debts to creditors. According to Retnowulan, bankruptcy is a general seizure (sita umum) of all property of the person who is declared bankrupt, existing at the time of the declaration of bankruptcy as well as obtained during the time at which bankruptcy takes place, for the benefit of all creditors, implemented under the supervision of the relevant authority. ${ }^{4}$

The Indonesian Bankruptcy Law does not recognize the principle of debt forgiveness, which means that bankruptcy is a legal means to alleviate the debtor's burden due to financial difficulties rendering it unable to repay its debts that are due, by providing debt relief through the elimination of remaining debts, so that the debtor can resume its business without being burdened by other debts. ${ }^{5}$

The debt forgiveness principle is implemented in the form of, among other things, debt relief granted to the debtor to pay off debts that are truly incapable of being fulfilled (discharge of indebtedness). ${ }^{6}$ It can also be implemented through debt relief to the debtor for debts it is unable to pay, thus enabling the debtor to start a new business without being burdened by previous problematic debts. ${ }^{7}$

As mentioned above, the principle of debt forgiveness is not recognized in the Indonesian Bankruptcy Law. Pursuant to Article 204 of the Bankruptcy Law, after the closure distribution list becomes binding, creditors regain property rights against the debtor regarding the execution of their unpaid receivables. Under the Bankruptcy Law, if following the completion of the liquidation process carried out by the curator there are debts remaining unpaid even though the bankruptcy estate has been sold and divided, the debtor remains obligated to repay such remaining debts to creditors, and the creditors are entitled to collect the remaining portion of the receivables.

After the termination of bankruptcy, the debtor is no longer in a state of bankruptcy,

${ }^{1}$ Indonesia, Undang-Undang tentang Kepailitan dan Penundaan Kewajiban Pembayaran Utang (Law on Bankruptcy and Suspension of Obligation for Payment of Debts), Undang-Undang Nomor 37 tahun 2004, LN No. 131 tahun 2004, TLN No. 4443 (Law No. 37 of 2004, SG No. 13 of 2004).

2 M. Hadi Subhan, Hukum Kepailitan Prinsip, Norma dan Praktik di Peradilan, [Bankruptcy Law, Principles, Norms and Practices in the Judicature]. 2nd ed. (Jakarta: Kencana Prenada Media Group, 2009), p.2.

3 Emmy Yuhassarie, "Pemikiran Kembali Hukum Kepailitan Indonesia [Rethinking Indonesia's Bankruptcy Law]," in Undang-Undang Kepailitan dan Perkembangannya [The Bankruptcy Law and Its Development], ed. Emmy Yuhassarie (Jakarta: Pusat Pengkajian Hukum, 2004), p. xix.

${ }^{4}$ Retnowulan Sutantio, Kapita Selekta Hukum Ekonomi Dan Perbankan [Selected Topics on Economic and Banking Law] Seri Varia Yustitia (Yogyakarta: Kanisius, 1996), p.85.

${ }^{5}$ Ibid., p.p.139.

${ }^{6}$ M Hadi Subhan, "Hukum Kepailitan," p.43.

7 Ibid., p.45. 
because at the time of such termination the bankruptcy status is revoked, hence the debtor is considered as being competent to manage his/her property. However, the termination of bankruptcy does not necessarily absolve the debtor from any remaining portion of such debt. Creditors are still entitled to collect the debt, and the debtor is obligated to pay such debt to creditors.

The bankruptcy of individual debtors is certain to have an impact on the business world, as bad loans are bound to create constraints in the business community and thus cause the economy to suffer. Businesses (individual bankrupt debtors) remain burdened by the obligation to repay their debts of the past, hence they do not have a chance to try to make a come back and have a fresh start, even if the debtor had been bankrupt and all its property had been sold to pay off its debts to creditors.

Similarly, after the termination of bankruptcy, the debtors or its heirs may apply for rehabilitation. However, rehabilitation will only be granted if all creditors have stated that they have received payment in a satisfactory manner, meaning that recognized creditors will not file claims against the debtor even though they may not have received payment on all of their receivables. Thus, as long as the debtor continues to have remaining unpaid debts, it is unable to apply for rehabilitation, because rehabilitation can only be granted if the debtor has completed the entire scheme of the bankruptcy and creditors are satisfied with the payment. In practice, not many rehabilitation petitions have been filed with the Commercial Court by bankrupt debtors or their heirs, whereas the rehabilitation petition is important to restore the good reputation and civil rights of the bankrupt debtor.

It is certainly not consistent with the original purpose underlying the establishment of the Bankruptcy Law, namely the need for a modern Bankruptcy Law for finding solutions or solving problems related to the repayment of debt at a time when the debtor is experiencing economic hardship or financial difficulty to its creditors. The underlying philosophy is to ensure that the bankruptcy process is implemented with the goal of maximizing returns on the rights of creditors in a fair and balanced manner, and also providing a way out for debtors who are struggling economically or financially as a result of being constantly pursued by creditors in order to pay off their debts.

In the course of its development, the Bankruptcy Law has become necessary in the business world for selecting businesses that are not effective, as companies that are not efficient can potentially affect the national economy and pose a burden on the economic system itself. ${ }^{8}$ It leads to an ongoing process of business for social benefits and the existence of business continuity. ${ }^{9}$

In principle, bankruptcy is the means of exiting from financial distress, as a way out of financial problems that can no longer be resolved, rather than being aimed at bankrupting the businesses that are still solvent. ${ }^{10}$ The principles of commercial exit from financial distress dictate that, particularly in the case of corporate insolvency, it is a way out for complicated issues which can no longer be resolved. ${ }^{11}$

8 Emmy Yuhassarie, ed., Prosiding Rangkaian Lokakarya Terbatas Masalah-Masalah Kepailitan dan Hukum Bisnis Lainnya [Proceedings Limited Workshop Series on Bankruptcy and other Business Law Related Issues] (Jakarta: Pusat Pengkajian Hukum, 2004).

9 Siti Anisah, "Studi Komparasi Terhadap Perlindungan Kepentingan Kreditor Dan Debitor Dalam Hukum Kepailitan [A Comparative Study on the Protection of Creditors' and Debtors' Interests under the Bankruptcy Law]," Jurnal Hukum 16, special issue (October 2009), p. 30.

10 Supriyono, "Perlindungan Para Kreditor Sehubungan dengan Debitor Mempailitkan Diri [The Protection of Creditors related to the Debtor's Self-Declared Bankruptcy,]" Jurnal Supremasi Hukum 2, no. 2 (December 2013), p. 3.

11 Ricardo Simanjuntak, "Esensi Pembuktian Sederhana Dalam Kepailitan [The Substance of Simple Proving Procedure in Bankruptcy]" in Prosiding Undang-Undang Kepailitan dan Perkembangannya [the 
Based on the foregoing, there is an issue which needs to be resolved with regards to the manner of dealing with the legal status of the bankrupt individual debtor after the termination of bankruptcy and the civil rights of the bankrupt individual debtor after the termination of bankruptcy associated with rehabilitation. The discussion of this writing is divided into several parts. The first part is the background which includes the research questions and the systematic of writing. The second part is a discussion of individual debtor's bankruptcy; and Part III is intended to discuss the termination of bankruptcy and rehabilitation, while part IV is reserved for the conclusion.

\section{INDIVIDUAL BANKRUPT DEBTOR}

Related to the bankruptcy of an individual debtor, Article 24 (1) Bankruptcy Law provides that the bankrupt debtor loses the right to manage and control its assets included as the bankruptcy property/estate, as from the time at which the bankruptcy decision is announced. The debtor only loses the civil right to manage and control its property, but continues to be able to undertake any other civil acts, such as marriage, or acting as custodian in the marriage of his/her children. According to Article 15 paragraph (1) in conjunction with Article 69 paragraph (1) of the Bankruptcy Law, as from the decision on bankruptcy, only the bankruptcy estate is under the curator's guardianship, the personal property of the bankrupt debtor is not.

In the event of the debtor's bankruptcy, the Bankruptcy Law does not distinguish between bankruptcy of a legal entity and a natural person. Article 1 sub-article 3 of the Bankruptcy Law provides that the debtor is a person who has debts due to agreements or by law, the repayment of which is capable of being claimed through the court of law. A person intended in Article 1 sub-article 11 of the Bankruptcy Law are individuals or corporations, including both corporate legal entities as well as nonlegal entities in liquidation. According to Article 3 (5) of the Bankruptcy Law, if the debtor is a legal entity, the seat of such legal entity shall be as defined in its statutes.

As the foregoing indicates, the scope of the Bankruptcy Law includes both individuals as well as corporate debtors either incorporated as a legal entity or a nonlegal entity. In fact, the distinction between the bankruptcy of individual arrangements and corporations either in the form of incorporated or non-incorporated entities is a highly important aspect given that there are significant differences in the following areas:

1). The party entitled to file a petition for the declaration of bankruptcy, in the event that the debtor is a corporation or a legal entity. In such case the relevant provisions of the law need to be referred to in determining who can act to represent the legal entity or non-legal entity concerned and the extent to which the action of such directors or partners is justified by the law.

2). the party responsible for paying the debts to creditors; it is related to personal accountability undertaken by the board of directors or the partners for actions undertaken on behalf of the legal entity or non-legal entity concerned. Conditions governing the liability of the legal entity or non-legal entity concerned to third parties as set forth in their respective legislation also need to be considered;

3). The application procedures for the declaration of bankruptcy in terms of applying, namely is the debtor itself considering the procedure for bankruptcy by different individuals or the procedure for bankruptcy by legal entities or non-legal entities, as well as the impact on bankruptcy debtors, especially with regards to the debt remaining after the

Proceedings on Bankruptcy Law and Its Development], ed., Emmy Yuhassarie (Jakarta: Pusat Pengkajian Hukum, 2004), p.55-56. 
termination of the bankruptcy.

By failing to distinguish between the bankruptcy of individuals and legal entities, including non-legal entities, the provisions of the Bankruptcy Law create uncertainty in implementation. In view of the various provisions on the debtor's liability to creditors for its debts which can be found in the Company Law (UU Perseroan Terbatas), the Cooperatives Law (UU Koperasi), Law on Foundations (UU Yayasan), State Owned Enterprises Law (UU BUMN), the Civil Code (KUH Perdata), and the Commercial Code $(K U H D)$ respectively, there is a lack of unified understanding of bankruptcy for natural persons, non-legal entities and legal entities.

The author conducted research at the Commercial Court of Central Jakarta, Semarang and Surabaya respectively, in view of petitions for the declaration of bankruptcy against individual debtors, regardless of whether they were filed by creditors or the debtors themselves. As the results of the said research indicate, in the period 1997-2014 the number of petitions for the declaration of bankruptcy of debtors filed by individuals either by creditors or debtors themselves indicates a significant increase each year, mainly at the Commercial Court of Surabaya. Thus it can be stated that bankruptcy is not only required by corporations but also individual debtors as a way out of their debt. The table below is based on data collected from the study conducted at the Jakarta Commercial Court in the period 1997-2013:

Table 1.

Petitions for the Declaration of Bankruptcy in Jakarta Commercial Court 1997-2013

\begin{tabular}{ccccc}
\hline Year & $\begin{array}{c}\text { Number of } \\
\text { Individual } \\
\text { Bankruptcy } \\
\text { Cases }\end{array}$ & Decision Number & $\begin{array}{c}\text { Bankruptcy } \\
\text { Petitioner }\end{array}$ & Decision \\
\hline 1997 & 1 & $\begin{array}{c}\text { Decision Number 01/ } \\
\text { Pailit/1997/PN.JKT/Ut }\end{array}$ & Debtor & $\begin{array}{c}\text { Bankruptcy decision } \\
\text { for Lie Nawaty }\end{array}$ \\
\hline 1998 & 1 & $\begin{array}{c}\text { Decision Number 13/ } \\
\text { Pailit/1998/PN.Niaga/Jkt.Pst }\end{array}$ & Creditor & $\begin{array}{c}\text { Bankruptcy decision } \\
\text { for Ira Chrysanti dan } \\
\text { Sani Rahardjo. }\end{array}$ \\
\hline 2008 & 1 & $\begin{array}{c}\text { Case Decision Number 19/ } \\
\text { Pailit/2008/PN.Niaga/Jkt Pusat }\end{array}$ & Debtor & $\begin{array}{c}\text { Bankruptcy decision } \\
\text { for Ms. Sandrawati }\end{array}$ \\
\hline & 1 & $\begin{array}{c}\text { Decision Number 10/ PDT.SUS } \\
\text { /PAILIT/ 2013/ PN.NIAGA.JKT. } \\
\text { PST }\end{array}$ & $\begin{array}{c}\text { Concurrent } \\
\text { creditor and } \\
\text { separatist }\end{array}$ & $\begin{array}{c}\text { Purdi E. Chandra was } \\
\text { declared bankrupt } \\
\text { with all legal } \\
\text { consequences. }\end{array}$ \\
\hline
\end{tabular}

Results of the interview with Rafita Lina, Coordinator of the Jakarta Commercial Court, indicate that in 2014 there were 48 bankruptcy cases in Jakarta, five of which were petitions for the bankruptcy of individuals, while the rest were petitions for the bankruptcy of limited liability companies $(P T)$. However, all of the individual bankruptcy cases are still in the process of the settlement of bankruptcy estate and are yet to be concluded with bankruptcy status. ${ }^{12}$

Based on observation at the Surabaya Commercial Court it was also found that

\footnotetext{
${ }^{12}$ Interview with Rafita Lina as Coordinator of the Jakarta Commercial Court, May 10, 2014.
} 
there were 41 bankruptcy decisions in which debtors included individuals, Usaha Dagang (hereinafter referred to a UD), and Commanditaire Venotschaap (hereinafter referred to as CV), namely 8 of them were $U D$ and $C V$, while the rest were individuals. Individual debtor bankruptcy decisions collected at the Surabaya Commercial Court included decisions filed by creditors or the debtors themselves. The list of bankruptcy decisions at the Surabaya Commercial Court is as follows:

Table 2.

Bankruptcy Decision at the Surabaya Commercial Court (UD and CV)

\begin{tabular}{|c|c|c|c|}
\hline No & Decision Number & Petitioner & Respondent \\
\hline 1 & 1/PAILIT/2002/PN.Niaga.Sby & Ny. Giok Sioe Als. Stefanus & CV Chandra Arvi Putra \\
\hline 2 & 09/Pailit/2007/PN.Niaga.Sby & UD Sahabat Elektrik & Heru Sulistyo, et al \\
\hline 3 & 10/Pailit/2007/PN.Niaga.Sby & Hendra Asali & CV Panen Limpah \\
\hline 4 & 08/Pailit/2008/PN.Niaga.Sby & Gunawan Alie & $\begin{array}{l}\text { Ang Fanny Angelina and CV De- } \\
\text { lima }\end{array}$ \\
\hline 5 & 12/Pailit/2010/PN.Niaga.Sby & Agus Susilo & CV Lentera Jaya \\
\hline 6 & 02/Pailit/2009/PN.Niaga.Sby & $\begin{array}{l}\text { Angka Wijaya alias Wibowo } \\
\text { dan_Maria Hanggawati }\end{array}$ & CV. Sinar Terang \\
\hline 7 & 10/Pailit/2011/PN.Niaga.Sby & Adi Istiarto dan Ir. Albert S. & CV Anugerah Dwi \\
\hline 8 & 25/Pailit/2011/PN.Niaga.Sby & $\begin{array}{l}\text { Gwo Hwan Ping dan Susie } \\
\text { Handyani }\end{array}$ & Endang Purwanti (UD SSS) \\
\hline 9 & 34/Pailit/2011/PN.Niaga Sby & PT BNI & $\begin{array}{l}\text { Dionisius A Siu Go (UD Surya } \\
\text { Mandiri) }\end{array}$ \\
\hline 10 & 12/Pailit/2012/PN.Niaga.Sby & UD Harapan Kita & \\
\hline 11 & 14/Pailit/2013/PN.Niaga.Sby & Santoso dan Moeljosantoso & CV B C Express \\
\hline
\end{tabular}

As for decisions on the declaration of bankruptcy of individual debtors submitted at the request of the creditors, they were as follows:

Table 3.

\section{Individual Bankruptcy Decision at the Surabaya Commercial Court (Applied by Creditor)}

\begin{tabular}{llll}
\hline \multirow{2}{*}{ Year } & \multicolumn{1}{c}{ Decision Number } & $\begin{array}{c}\text { Bankruptcy } \\
\text { Applicant (Credi- } \\
\text { tor) }\end{array}$ & \multicolumn{1}{c}{ Verdict } \\
\hline 2010 & $\begin{array}{l}\text { Decision Number: 28/Pailit/2010/ } \\
\text { PN.Niaga.Sby }\end{array}$ & $\begin{array}{l}\text { Darno } \\
\text { of Mrs. Dra. Herlina Handoko }\end{array}$ \\
\hline 2010 & $\begin{array}{l}\text { Decision Number: 05/Pailit/2010/ } \\
\text { PN.-Niaga Sby }\end{array}$ & Arie Mandha & Widi Kuscahyono and Puriyanto \\
\hline 2010 & $\begin{array}{l}\text { Decision Number: 10/Pailit/2010/ } \\
\text { PN.-Niaga Sby }\end{array}$ & $\begin{array}{l}\text { Purwan Habibie } \\
\text { Siswanto }\end{array}$ & $\begin{array}{l}\text { Passing a decision on the bankruptcy } \\
\text { of Lihan }\end{array}$ \\
\hline 2013 & $\begin{array}{l}\text { Decision Number: 10/Pailit/2013/ } \\
\text { PN.-Niaga Sby }\end{array}$ & $\begin{array}{l}\text { Sugiono } \\
\text { of Andre Martinus Wistorohardjo }\end{array}$ \\
\hline
\end{tabular}




\begin{tabular}{llll}
\hline 2013 & $\begin{array}{l}\text { Decision Number: 03/Pailit/2013/ } \\
\text { PN.Niaga.Sby }\end{array}$ & $\begin{array}{l}\text { PT Bank Rakyat } \\
\text { Indonesia }\end{array}$ & $\begin{array}{l}\text { Passing a decision on the bankruptcy } \\
\text { of Gusti Pello }\end{array}$ \\
\hline 2013 & $\begin{array}{l}\text { Decision Number: 19/Pailit/2013/ } \\
\text { PN.Niaga.Sby }\end{array}$ & $\begin{array}{l}\text { Alfonsus Widijat- } \\
\text { mika }\end{array}$ & $\begin{array}{l}\text { Passing a decision on the bankruptcy } \\
\text { of I Gusti Putu Wirawan }\end{array}$ \\
\hline 2013 & $\begin{array}{l}\text { Decision Number: 43/Pailit/2013. } \\
\text { PN.-Niaga.Sby }\end{array}$ & Swie Swat Isman & $\begin{array}{l}\text { Passing a decision on the bankruptcy } \\
\text { of Prayitno }\end{array}$ \\
\hline
\end{tabular}

In addition to the above, decisions on the declaration of bankruptcy applied for by individual debtors are among others as follows:

Table 4.

Individual Bankruptcy Decision at the Surabaya Commercial Court (Applied by Individual Debtors)

\begin{tabular}{llll}
\hline Year & Decision Number & $\begin{array}{c}\text { Bankruptcy Applicant } \\
\text { (Debtor) }\end{array}$ & \multicolumn{1}{c}{ Verdict } \\
\hline \multirow{2}{*}{$\begin{array}{l}\text { Decision Number: } \\
\text { Pailit/2009/PN.Niaga.Sby }\end{array}$} & $\begin{array}{l}\text { 02/ } \\
\text { Angka Wijaya alias Wi- Passing a decision on the bankruptcy of } \\
\text { gawati }\end{array}$ & $\begin{array}{l}\text { Angka Wijaya alias Wibowo dan Maria } \\
\text { Hanggawati (CV. Sinar Terang) }\end{array}$ \\
\hline 2014 & $\begin{array}{l}\text { Decision Number: } \\
\text { Pailit/2014/PN.Niaga.Sby }\end{array}$ & Ali Tjandra Soetjipto & $\begin{array}{l}\text { Passing a decision on the bankruptcy of } \\
\text { Ali Tjandra Soetjipto }\end{array}$ \\
\hline
\end{tabular}

Bankruptcy cases involving individual debtors and banks are as indicated in the following Decisions:

Table 5.

Individual Bankruptcy Decision at the Jakarta Commercial Court (Involving Individual Debtors and Banks)

\begin{tabular}{|c|c|c|c|}
\hline Year & Decision Number & $\begin{array}{c}\text { Bankruptcy Ap- } \\
\text { plicant }\end{array}$ & Verdict \\
\hline 2000 & $\begin{array}{l}\text { Decision Number 021/PKPU/2000/ } \\
\text { PN.Niaga.Jkt. } \\
\text { Pst jo 078/Pailit/2000/PN.Niaga.Jkt.Pst } \\
\text { tertanggal } 13 \text { Maret 2001 }\end{array}$ & $\begin{array}{l}\text { Bank IFI and Bank } \\
\text { Singapore }\end{array}$ & $\begin{array}{l}\text { Passes a decision on the bank- } \\
\text { ruptcy of Ir. Fadel Muhammad } \\
\text { with all legal consequences }\end{array}$ \\
\hline 2013 & $\begin{array}{l}\text { Decision Number 10/Pdt.Sus/ } \\
\text { PKPU/2013/PN.Niaga.Jkt.Pst.jo Nomor } \\
\text { 10/Pst.Sus/Pailit,2013/PN.Niaga.Jkt.Pst }\end{array}$ & $\begin{array}{l}\text { PT Bank BNI Sya- } \\
\text { riah }\end{array}$ & $\begin{array}{l}\text { Passes a decision on the bank- } \\
\text { ruptcy of } \\
\text { E. Chandra with all legal conse- } \\
\text { quences }\end{array}$ \\
\hline 2013 & 03/Pailit/2013/ & $\begin{array}{l}\text { PT Bank Rakyat } \\
\text { Indonesia }\end{array}$ & $\begin{array}{l}\text { Passes a decision on the bank- } \\
\text { ruptcy of Gusti Pello with all legal } \\
\text { consequences }\end{array}$ \\
\hline
\end{tabular}

In comparison, the United States Bankruptcy Code regulates the bankruptcy scheme for partnership, corporations, as well as individuals, and it also applies for 
municipality legal entities. However, the Bankruptcy Code excludes debtors in the form of railroad companies, insurance companies, and banking institution. There are two general forms of bankruptcy, namely 1) liquidation; and 2) rehabilitation. Individual bankruptcy is provided for under Chapter 7 regarding liquidation without limitation of debt. Furthermore, Chapter 11 deals with reorganization without limitation of debt; Chapter 12 is specifically intended for families who own farming enterprises the debt of which does not exceed US $\$ 1,500,000$; Chapter 13 provides for debtors who earn a stable and routine income, and have the secured debts not exceeding $\$ 350,000$ and not exceeding $\$ 100,000$ for unsecured debts. ${ }^{13}$

In the Netherlands, the regulation of natural person/individual bankruptcy is regulated under the Debt Restructuring of Private Individuals Act or Wet Schuldsanering Natuurlijke Personen (WSNP) which has been in force since December 1,1998 . WSNP is provided for in Book III of Faillissementswet. The said regulation provides that a natural person/individual, regardless of whether or not such natural person/individual is conducting a business and that only a natural personal/ individual can apply for debt restructuring. ${ }^{14}$

In Singapore, individual bankruptcy is regulated under the Bankruptcy Ordinance of 1888. Based on the foregoing it is evident that the bankruptcy laws in the United States, the Netherlands, and Singapore respectively draw a clear distinction between the bankruptcy of individuals and corporations. At the same time, as described above, the Indonesian Bankruptcy Law does not distinguish between the bankruptcy of individuals and legal entities. In some cases, there are differences in the arrangement between the bankrupt individual debtor and legal entity or non-legal entity, among others, the provision of debt relief can only be granted to individual debtors alone, which is due to the fact that a legal entity can be dissolved after the bankruptcy itself, while the obligation for the remaining debt will continue to be attached to the individual debtor concerned.

\section{TERMINATION OF BANKRUPTCY AND REHABILITATION}

The status of declared bankruptcy ends if the following conditions occur:

(a) The cancellation of the bankruptcy declaration decision;

According to Article 16 paragraph (2) of the Bankruptcy Law:

"In the event that the bankruptcy declaration decision is cancelled following cassation or judicial review, any acts that have been taken by the Curator prior to or on the date on which the Curator receives notice of the cancellation decision as referred to in Article 17 shall remain valid and binding upon the Debtor."

Article 17 paragraph (1) of the Bankruptcy Law provides as follows:

"The Curator shall be obligated to announce the cassation or judicial review decision cancelling the bankruptcy decision in the Official Gazette of the Republic of Indonesia and in at least 2 (two) newspapers as referred to in Article 15 paragraph (4)."

${ }^{13}$ David G. Epstein, Steve H. Nickles and James J. White, Bankruptcy (St. Paul Minn: West Publishing Co, 1993), p.8.

${ }^{14}$ N.J. Polak, Faillissementsrecht (Denver: Kluwer, 2005), p.302. 
(b)Revocation of the bankruptcy declaration decision;

According to Article 18 paragraph (1) of the Bankruptcy Law:

"In the event that the bankruptcy assets are not sufficient to cover the bankruptcy charge, the Court upon recommendation of the Supervisory Judge and after consulting with the temporary Creditor Committee, if any, and after summoning and hearing the Debtor, may decide to cancel the bankruptcy decision."

Revocation of bankruptcy due to the unavailability of assets can also occur when the settlement of bankruptcy assets is completed and the debtor's bankruptcy assets are completely divided and distributed to the creditors. For the said reasons, the curator may apply for the revocation of bankruptcy to the Commercial Court based on the unavailability of assets under Article 18 of the Bankruptcy Law, thus ending the bankruptcy.

(c) Termination of bankruptcy occurring based on accord;

In Article 166 paragraph (1) of the Bankruptcy Law it is stated that:

"Once the ratification of the draft reconciliation has become final and conclusive, the bankruptcy will be ceased."

The curator must announce the accord in the Official Gazette of the Republic of Indonesia and in at least two (2) daily newspapers circulated nationally and locally as stipulated in Article 166 paragraph (2) of the Bankruptcy Law.

(d) Following the full repayment of debt to the creditor, or immediately after the closure distribution list becomes binding;

According to Article 202 paragraph (1) of the Bankruptcy Law:

"Immediately after the verified creditors are paid in full, or immediately after the last distribution list becomes legally binding, the bankruptcy will cease without prejudice to the provisions of Article 203."

The curator's next action is to make an announcement of the termination of bankruptcy in the Official Gazette of the Republic of Indonesia and the newspapers as intended in Article 202 paragraph (2) of the Bankruptcy Law.

The end of bankruptcy reinstates the debtor into his/her original state prior to the bankruptcy. With the end of bankruptcy, the debtor is fully entitled to conduct the management and transfer of rights of its assets; however, the termination itself does not relieve the debtor from the debts that are not fully paid. Under Article 204 of the Bankruptcy Law, the creditors regain the right of execution against the debtor's property for their receivables. In other words, even after the bankruptcy has ended, while there are still remaining unpaid debts, the debtor will continue to have the obligation to pay the rest of the debts to its creditors, and the creditors also continue to have the right to collect such unpaid debts. Creditors' execution right for their receivables remaining unpaid are also reinforced with the provisions of Article 205 of the Bankruptcy Law, which state that receivables recorded in the Minutes of Meeting (Berita Acara Rapat) have legal binding force against the debtor just as a court decision which has obtained final and binding force.

The considerations of bankruptcy judges at the Semarang Commercial Court and the Central Jakarta Commercial Court with respect to the end of the bankruptcy and the treatment of unpaid debts remaining after the closure distribution list becomes 
permanently binding are as reflected in the decisions below:

1. Decision Number 001/Rehabilitasi Kepailitan/2000/PN.Niaga.Jkt.Pst with the verdict stating that PT Batamas Jala has paid its debts to the creditors, hence the panel found that the bankruptcy of PT Batamas Jala has terminated;

2. Decision Number $05 \mathrm{~K} / \mathrm{N} / 2004$ with the verdict stating to revoke bankruptcy declaration for the applicant (Ir Fadel Muhammad) with all legal consequences;

3. Decision Number 03/HP/VI/2011-80/PAILIT/2010/PN.NIAGA.JKT.PST with the verdict stating that the bankruptcy assets distribution list of PT Ecom International has obtained final and binding status, and under Article 202 paragraph (2) of the Bankruptcy Law, the bankruptcy is terminated. Furthermore, in the minutes of distribution and payment, there are still unpaid debts of PT Ecom International to the creditors, whereby in accordance with the provisions of Article 204 of the Bankruptcy Law, the creditors still have the execution rights with regards to their unpaid receivables.

4. Decision 03/Pailit/2012/PN.Niaga.Smg with the verdict stating that the closure distribution list of PT Kasega Dadidit has a binding force, thus the bankruptcy has ended by the operation of law. Furthermore, according to the closure distribution list there are still unpaid debts of PT Kasega Dadidit, whereby according to the provisions of Article 204 of the Bankruptcy Law, if it is subsequently found that there are debtor's assets which still exist, the creditors still have the right to execute the unpaid receivables.

Based on the above discussion, the termination of bankruptcy can occur based on the cancellation of the bankruptcy decision; revocation of the bankruptcy declaration decision; termination of bankruptcy that occurs due to reconciliation (accord); full payment of the creditors' receivables, or immediately after the closure list of distribution becomes binding. In the event after the termination of bankruptcy, particularly after the closure distribution list becomes binding and yet there are still unpaid debts left, the creditors still have the execution right with respect to unpaid debts, hence the debtor will not obtain a waiver of the remainder of such debt, and consequently the remaining debt will continue to follow the individual debtor until it is fully paid.

The above described condition causes difficulties for the bankrupt debtor, especially in view of its ability to recover and make a fresh start, because it will continue to be overshadowed by its old debts to creditors as long as the debt is not repaid. The remainder of the debt will continue to follow the individual bankrupt debtor, even allowing the debtor to become bankrupt for the second time. Under the Bankruptcy Law, there is no specified time limit for the creditor to collect the remaining receivables. However, based on the provisions of Article 1967 of the Indonesian Civil Code, the expiration period of a claim is 30 years if the creditors remain silent, but such expiration period will be interrupted if there is a warning issued by the Court of law (Article 1979 of the Indonesian Civil Code). ${ }^{15}$

The above stands in contrast to the status of bankrupt debtor incorporated in the form of a legal entity such as a limited liability company (Perseroan Terbatas, PT). Article 142 of the Indonesian Company Law No. 40 of 2007 (Undang-Undang Perseroan Terbatas, hereinafter referred to as "UUPT") states that in the event that the bankruptcy assets are insufficient to pay the debts, the bankrupt corporation concerned will be dissolved by operation of law, hence it will not bear the burden of paying the remaining debt after the bankruptcy ends. ${ }^{16}$ At the same time, according

${ }^{15}$ Gunawan Widjaja, Seri Hukum Bisnis: Daluwarsa [Business Law Series: Expiry (of a time limit to bring an action)] (Jakarta: RajaGrafindo Persada, 2005), p. 89.

16 Zaeni Asyhadie and Budi Sutrisno, Hukum Perusahaan dan Kepailitan Company and Bankruptcy Law] 
to Article 142 paragraph (1) sub-paragraph e, once the company assets are declared bankrupt in a state of insolvency, the company will be dissolved.

Insolvency is a situation that demonstrates the inability (state of stopping payment) of the company concerned in order to meet its debt obligations or experiencing a shortage of money to pay its debts. ${ }^{17}$ Such inability is not caused by trivial matters; rather, it is caused by substantial problems making it difficult to sustain the company's business activities. ${ }^{18}$ According to M. Hadi Subhan, a company is in the state of insolvent bankruptcy if the book value of its total liabilities exceeds the market value of its total assets. ${ }^{19}$ In theory, the doctrine of insolvency test is ideal as a basis for declaration of a bankrupt debtor. In practice, however, it is rather difficult to be applied in the court of law. It is particularly true when faced with the simple proving authority. ${ }^{20}$ At the same time, the Bankruptcy Law itself does not apply the insolvency test as a requirement for declaring bankruptcy. As long as the requirement for bankruptcy under Article 2 paragraph (1) of the Bankruptcy Law is fulfilled, the debtor concerned may be declared bankrupt.

Also, the Bankruptcy Law does not distinguish between bankrupt debtors in the form of corporation or individuals. At the same time, there is a fundamental difference between individual debtors and corporation debtors, both in terms of form, arrangements, procedures for bankruptcy, as well as the result of bankruptcy, especially in view of unpaid debt remaining after the termination of bankruptcy. Such condition is certainly considered unfair by individual debtors, as individual debtors will continue to be pursued for the payment of remaining debts, without a specific and definite time limit. On the other hand, a corporation debtor can dissolve itself in the event of bankruptcy and it will no longer bear the burden for remaining debts. It is considered to be inconsistent with the principle underlying the establishment of the Bankruptcy Law as mentioned in the elucidation part, namely that the Bankruptcy Law is based on the principles of balance, fairness, business continuity and integration. According to Sutan Remy Sjahdeini, the Bankruptcy Law should be able to provide protection not to the creditors only, but rather, the interests of the debtors must also be equally considered. ${ }^{21}$

Furthermore, after the termination of bankruptcy, the debtors or its heirs may apply for rehabilitation; however, rehabilitation will only be granted if all creditors state that they have been paid satisfactorily, meaning that recognized creditors will not file claims again against the debtor even though they may not have received payment for the entire debt. Thus, as long as the debtor has remaining unpaid debts, it is not able to apply for rehabilitation, because rehabilitation can only be granted if the debtor has completed the entire scheme of the bankruptcy and creditors are satisfied with the payment.

The consequence of remaining unpaid debts despite the bankruptcy having ended is that the bankrupt debtor is unable to apply for rehabilitation. Under Article 215 of

(Jakarta: Erlangga, 2012), pp.111-112.

17 Slamet B. Noor, Kamus Akutansi, [Accounting Dictionary] (Jakarta : Majalah Keuangan, 1988), p. 245.

18 Paripurna P. Sugarda, "Definisi Utang Menurut RUU Kepailitan dan Penundaan Kewajiban Pembayaran Utang [The Definition of Debt According to the Draft Law on Bankruptcy and the Postponement of Debt Obligation Payment]," Jurnal Hukum Bisnis 17 January 2002.

${ }^{19}$ M. Hadi Subhan, "Insolvency Test: Melindungi Perusahaan Solven Yang Beritikad Baik Dari Penyalahgunaan Kepailitan [Insolvency Test: Protecting Solvent Companies Acting in Good Faith Against the Abuse of Bankruptcy]," Jurnal Hukum Bisnis 3 (2014).

${ }^{20}$ Ricardo Simanjuntak, "Aspek Hukum Kepailitan Publik Di Pasar Modal [Legal Aspects of Public Bankruptcy Law on the Stock Market]," Jurnal Hukum Pasar Modal 5 (2013), p.13.

${ }^{21}$ Sutan Remy Sjahdeini, "Perlindungan Debitor dan Kreditor Dampak Undang-Undang Kepailitan Terhadap Perbankan [The Protection of Debtors and Creditors Impact of the Bankruptcy Law on the Banking Sector]," Jurnal Hukum Bisnis 5 (2008), p.6 
the Bankruptcy Law, after the bankruptcy ends because the debts are fully paid, or after the closure distribution list obtains permanent binding force, the debtor or its heirs can apply for rehabilitation. According to the elucidation on Article 215 of the Bankruptcy Law, rehabilitation is a vindication of the originally declared bankrupt debtor by a court decision which contains the information stating that the debtor has fulfilled its obligations.

Rehabilitation may be granted if the debtor's debts have been resolved according to the procedure of bankruptcy. Rehabilitation is granted as a means of restoration of the debtor's civil rights to control and take care of its assets. Through rehabilitation, the debtor's reputation will be restored so that it can conduct its business just like before the bankruptcy. ${ }^{22}$ Thus, the decision on rehabilitation is expected to restore the good reputation and civil rights of the bankrupt debtor in particular, the property right or the right to its assets. By law, the bankrupt debtor status would be restored through rehabilitation, as if there had never been a bankruptcy in the first place, so the debtor is able to manage its property and restart its business.

According to Article 216 of the Bankruptcy Law, the request for rehabilitation filed by a debtor or its heirs would not be granted unless attached to the application letter there is proof stating that all recognized creditors have already received the payment satisfactorily. With reference to the elucidation on Article 216 of the Bankruptcy Law, "satisfactory payment" is intended to mean that the recognized creditors will not file a claim against the debtor even though they have not received full payment of the debts. Thus, if it is proved that all creditors have received satisfactory payment either because all of the receivables have been paid or the receivables have been paid only partially, but the creditors decide to let it go and will not file claims for the remaining unpaid debts, the Commercial Court will grant the petition for rehabilitation proposed by the bankrupt debtor or its heirs. If it is proven that the creditors have not received satisfactory payment, the debtor or its heirs will not be able to apply for rehabilitation, hence the debtor is unable to restore its good reputation and civil rights to manage and control its own property.

As long as the debtor has not received rehabilitation, it would be difficult for it to get back to its business, hence, it is important for the debtor or its heirs to apply for the rehabilitation request. In practice, there are few debtors or their heirs who apply for the rehabilitation request following the termination of bankruptcy. This is due to the fact that such request is a right, rather than an obligation, for debtors and their heirs hence the choice is up to them as to whether or not they exercise such right. According to the opinion of Ifa Sudewi, Vice Chairperson of the Semarang District Court, the request for termination of bankruptcy should also be followed by rehabilitation request, so that the decision on termination should be an inseparable part of the rehabilitation decision. ${ }^{23}$

On a similar note, based on the remarks given by bankrupt debtors it can be concluded that almost all debtors stated that they never applied for rehabilitation, because as soon as the decision on the bankruptcy status is passed, the corporation/ PT at which they serve as director becomes dissolved hence it does not require rehabilitation. According to the Registrar of the Surabaya Commercial Court, nobody files a rehabilitation request because in practice the settlement of bankruptcy assets requires a relatively long period of time. Based on existing data at the Surabaya Commercial Court, the settlement of bankruptcy assets has been ongoing for almost five years, so that a decision on bankruptcy termination is yet to be passed. ${ }^{24}$

Without the decision on bankruptcy termination, the request for rehabilitation

\footnotetext{
${ }^{22}$ M. Hadi Subhan, "Hukum Kepailitan," p.45.

${ }^{23}$ Interview with Ifa Sudewi, Vice Chairperson of the Semarang District Court, June 15, 2014.

${ }^{24}$ Interview with the Registrar of the Surabaya Commercial Court, August 26, 2016.
} 
cannot be filed. Similarly, after the decision on bankruptcy, the creditors are still not satisfied with the debt payment, and continue to collect the remaining unpaid debts. Thus, without the decision on the termination of bankruptcy and the evidence that the creditors have received satisfactory payment, the debtor or its heirs cannot apply for rehabilitation. The debtor's right to obtain vindication and civil rights in property are impeded without any certainty regarding the time limit, as long as the requirements to apply for rehabilitation are not met. At the same time, rehabilitation is important to restore the reputation of the debtor among business circles, and to restore its right to control and manage its property thus enabling it to resume its business operations.

\section{CONCLUSION}

The termination of debtor's bankruptcy can occur either due to the cancellation of the bankruptcy declaration decision; termination of bankruptcy that occurred based on accord; and full payment of the debt to the creditors, or terminated immediately after the closure distribution list becomes binding. The termination of the debtor's bankruptcy restores the debtor's status into its original state prior to the declaration of bankruptcy, which means that the legal status of the bankrupt debtor after the end of bankruptcy is that the debtor concerned is no longer in a state of bankruptcy. With the end of bankruptcy, the debtor is fully entitled to undertake acts to manage and transfer rights on its property.

The termination of bankruptcy does not necessarily absolve the debtor from debts that are not fully paid. Under Article 204 of the Bankruptcy Law, creditors regain execution rights on the debtor's property in terms of the creditors' unpaid receivables. That is to say, even when the bankruptcy has ended, yet there are remaining unpaid debts, the debtor has an obligation to pay the remainder of such debts to its creditors, and the creditors will continue to have the right to collect such unpaid debts. The creditors' execution right on unpaid debts is also supported by the provisions of Article 205 of the Bankruptcy Law setting forth that receivables recorded in the Minutes of Meeting (Berita Acara Rapat) shall be legally enforceable against the debtor just as a court decision that has obtained permanent binding force. Thus, the debtor will not obtain a waiver of the remaining debt even if the bankruptcy has ended, and consequently the remaining unpaid debt will continue to be attached to the individual debtor until the debt is fully repaid.

After the bankruptcy ends, the debtor or its heirs may apply for rehabilitation under Article 215 of the Bankruptcy Law. Rehabilitation is a vindication of debtor originally declared bankrupt by a court decision stating that the debtor has fulfilled its obligations. Under Article 216 of the Bankruptcy Law, a petition for rehabilitation by a debtor or its heirs will not be granted unless the letter of request is accompanied by evidence that all of the recognized creditors have received payment in a satisfactory manner. If proven that the creditors have not received satisfactory payment, the debtor concerned or heirs will not be able to file a rehabilitation request, hence the debtor concerned will not able to restore its good reputation and civil rights to manage and control its property. Accordingly, rehabilitation is only granted if all debts have been resolved according to the procedure of bankruptcy. At the same time, rehabilitation is important for the business continuity and livelihood of the bankrupt debtor in the future because through rehabilitation, the debtor receives vindication and regains civil rights to administer and control its property. 


\section{Bibliography}

\section{Legal Documents}

Indonesia. Undang-Undang tentang Kepailitan dan Penundaan Kewajiban Pembayaran Utang (Law on Bankruptcy and Suspension of Obligation for Payment of Debts). Undang-Undang Nomor 37 tahun 2004, LN No. 131 tahun 2004, TLN No. 4443 (Law No. 37 of 2004, SG No. 13 of 2004).

\section{Books}

Asyhadie, Zaeni dan Budi Sutrisno. Hukum Perusahaan dan Kepailitan [Company and Bankruptcy Law]. Jakarta: Erlangga, 2012.

Epstein, David G. et al., Bankruptcy. St. Paul, Minn: West Publishing Co, 1993.

Noor, Slamet B. Kamus Akutansi. Jakarta : Majalah Keuangan, 1988.

Polak, N. J.. Faillissementsrecht. Denver: Kluwer, 2005.

Subhan, M. Hadi. Hukum Kepailitan Prinsip, Norma dan Praktik di Peradilan [Bankruptcy Law, Principles, Norms and Practices in the Judicature]. $2^{\text {nd }}$ ed. Jakarta: Kencana Prenada Media Group, 2009.

Widjaja, Gunawan. Seri Hukum Bisnis: Daluwarsa [Business Law Series: Expiry (of a time limit to bring an action)]. Jakarta: RajaGrafindo Persada, 2005.

Yuhassarie, Emmy. "Pemikiran Kembali Hukum Kepailitan Indonesia" ["Rethinking Indonesia's Bankruptcy Law"], in Emmy Yuhassarie, ed. UndangUndang Kepailitan dan Perkembangannya [The Bankruptcy Law and Its Development]. Jakarta: Pusat Pengkajian Hukum, 2005.

Yuhassarie, Emmy. Prosiding Rangkaian Lokakarya Terbatas Masalah-Masalah Kepailitan dan Hukum Bisnis Lainnya [Proceedings Limited Workshop Series on Bankruptcy and other Business Law Related Issues]. Jakarta: Pusat Pengkajian Hukum, 2005.

Simanjuntak, Ricardo. "Esensi Pembuktian Sederhana Dalam Kepailitan." dalam Prosiding Undang-Undang Kepailitan dan Perkembangannya. ["The Substance of Simple Proving Procedure in Bankruptcy." In the Proceedings Bankruptcy Law and Its Development]. Jakarta: Pusat Pengkajian Hukum, 2005.

Sutantio, Retnowulan. Kapita Selekta Hukum Ekonomi Dan Perbankan [Selected Topics on Economic and Banking Law] Seri Varia Yustitia. Yogyakarta: Kanisius. 2006.

\section{Articles}

Anisah, Siti. "Studi Komparasi Terhadap Perlindungan Kepentingan Kreditor Dan Debitor Dalam Hukum Kepailitan [A Comparative Study on the Protection of Creditors' and Debtors' Interests under the Bankruptcy Law]." Jurnal Hukum 16, special issue (October 2009).

Simanjuntak, Ricardo. “Aspek Hukum Kepailitan Publik Di Pasar Modal." [“Legal Aspects of Public Bankruptcy Law on the Stock Market."] Jurnal Hukum Pasar Modal 5 (2013) 
Sjahdeini, Sutan Remy. "Perlindungan Debitor dan Kreditor Dampak UndangUndang Kepailitan Terhadap Perbankan [The Protection of Debtors and Creditors Impact of the Bankruptcy Law on the Banking Sector]." Jurnal Hukum Bisnis 5 (2008).

Subhan, M. Hadi. "Insolvency Test: Melindungi Perusahaan Solven Yang Beritikad Baik Dari Penyalahgunaan Kepailitan [Insolvency Test: Protecting Solvent Companies Acting in Good Faith Against the Abuse of Bankruptcy]." Jurnal Hukum Bisnis 3 (2014).

Sugarda, Paripurna P. "Definisi Utang Menurut RUU Kepailitan dan Penundaan Kewajiban Pembayaran Utang [The Definition of Debt According to the Draft Law on Bankruptcy and the Postponement of Debt Obligation Payment]. Jurnal Hukum Bisnis 17 (January 2002).

Supriyono. "Perlindungan Para Kreditor Sehubungan Dengan Debitor Mempailitkan Diri "The Protection of Creditors related to the Debtor's Self-Declared Bankruptcy]." Jurnal Supremasi Hukum 2, no. 2 (December 2013). 
言 